\title{
Cork Fish Bone Residue of Enrichment Wet Noodle: Chemical and Sensory Characteristic
}

\author{
${ }^{1 s t}$ Yuli Hartati \\ Department of Nutrition \\ Poltekkes Kemenkes Palembang \\ Palembang, Indonesia \\ yuli.hartati@poltekkespalembang
}

\author{
2nd Widya Arum \\ Department of Nutrition \\ Poltekkes Kemenkes Palembang \\ Palembang, Indonesia \\ widyaarm@gmail.com
}

\author{
${ }^{3 r d}$ Fathiyah Rusvizah \\ Department of Nutrition \\ Poltekkes Kemenkes Palembang \\ Palembang, Indonesia \\ dkhasanahputri@gmail.com
}

\author{
4th Khasanah Putri \\ Department of Nutrition \\ Poltekkes Kemenkes Palembang \\ Palembang, Indonesia \\ fathiyah041@gmail.com
}

Corresponding author: yuli.hartati@ poltekkespalembang

\begin{abstract}
Fish bones are a form of waste generated from the fish processing industry. Fish bones still contain nutrients the body needs, especially calcium. One of the fish bones that has the potential to be used in food processing is snakehead fish bones. Red dragon fruit is a fruit that contains high fiber and to determine the effect of adding cork bone meal and dragon fruit on the characteristics and acceptability of fresh noodles. The research design used a non-factorial Completely Randomized Design (CRD) with 4 formulas and 3 replications. Data analysis used Friedman test. The results showed that $P 1$ was the most preferred formula for the panelists. Fresh noodles with the addition of snakehead fish bone meal and dragon fruit with different proportions in each treatment had a significant effect on the abilityto taste, color and aroma of fresh noodles.
\end{abstract}

Keywords: Wet noodles, Cork fish bone flour, Dragon fruit, Acceptability.

\section{INTRODUCTION}

Wet noodles are foods made from flour, salt and water and other food additives [1]. Wet noodles are raw noodles that before being marketed boil in boiling water, with a water content of about $35 \%$ and after boiling the water content increases to $52 \%$. Relatively high water content results in a short shelf life [2]. According to the 2015 Indonesian Food Consumption Statistics data, the consumption of wet noodles in 2014 reached $0.05 \mathrm{~kg}$ per capita per year. This led to a very high level of dependence on wheat flour, so that wheat imports continued to increase, according to the Ministry of Agriculture's Pusdatin data in 2015 wheat imports reached 223,000 tons so it is necessary to make an effort to look for other ingredients that can replace some of the flour by not reducing the nutritional value of the food, for example, fishbone flour and dragon fruit [3]. Data in Indonesia
Food Research Center for Calcium Consumption in Indonesia is still very low, at $254 \mathrm{mg} /$ day while the standard of calcium consumption for adolescents is $1200 \mathrm{mg} / \mathrm{day}$. Sources of calcium can be obtained from various foodstuffs, namely milk, cheese, eggs and fish [4].

Bone is one form of waste produced from the fish processing industry which has the most calcium content in the body of the fish. Fish bones contain many mineral salts such as calcium phosphate and keratin phosphate which have the potential to improve the nutrition of food products is cork fish (Yenrina and Kasim, 1993; [6]. This is supported by the amount of cork fish production in the South Sumatra Region which reached 5,702 tons in 2008 [7].

Red dragon fruit is one fruit contains substances that are good for the body, especially substances that play a role in reducing total blood cholesterol levels, such as antioxidant compounds (phenols, flavonoids, vitamin $\mathrm{C}$ and betacyanin), vitamin B3 (niacin), fiber, MUFA (monounsaturated fatty acids), and (polyunsaturated fatty acids) (Lokaria and Harmoko, 2018). Fruit that is high in fiber which is 3.2 grams per 100 grams of material [8].

\section{METHODS}

\section{A. Material and Tools}

The ingredients used in this wet noodle study are wheat flour, cork fish bone flour, and dragon fruit. Additional ingredients needed are eggs, salt. The equipment used in this research was basin, gas stove, pan, presto, blender, flour sieve, cauldron, wooden spoon, stainless steel spoon, basin, plate, rebar, tissue, digital scales, plastic gloves, plastic gloves, noodles (Hou, 2001). 


\section{B. Research Sites}

The study was conducted in the food technology laboratory and sensory evaluation laboratory majoring in nutrition at the Health Polytechnic of the Ministry of Health, Palembang.

\section{Research Design}

This study was an experimental study using a nonfactorial Completely Randomized. The treatments examined included the proportion of the incorporation of materials as follows:

\begin{tabular}{lcccc}
\multicolumn{5}{c}{ Table 1. Ingredient Formulation for Making Wet Noodles } \\
\hline & P0 & P1 & P2 & P3 \\
\hline Wheat flour (g) & 100 & 80 & 70 & 60 \\
& & & & \\
\hline $\begin{array}{l}\text { Cork Fish Bone } \\
\text { Flour (g) }\end{array}$ & 0 & 20 & 30 & 40 \\
\hline Dragon fruit (g) & 0 & 50 & 50 & 50 \\
\hline Egg (g) & 30 & 30 & 30 & 30 \\
\hline Salt (g) & 2 & 2 & 2 & 2 \\
\hline Water (g) & 25 & 0 & 0 & 0 \\
\hline Total & 157 & 182 & 182 & 182 \\
\hline
\end{tabular}

Information:

a) $\mathrm{P} 0=100$ gram wheat flour +0 gram cork fish bone flour +0 gram dragon fruit

b) $\mathrm{P} 1=80$ gram flour +20 grams cork bone meal + 50 grams dragon fruit

c) P2 $=70$ grams of flour +30 grams of cork fish bone flour +50 grams of dragon fruitd)

d) P3 $=60$ gram flour +40 grams cork fish bone flour +50 grams dragon fruit

\section{Data Collection Methods}

Data collection methods used in this study include organoleptic testing. The organoleptic test is carried out using a scale score of 1 - 5 with the categories of very dislike, dislike, rather like, like, like very much. The organoleptic test was conducted by 30 panelists. Proximate analysis or chemical testing was carried out to determine the chemical composition of the wet noodle products of cork fish flour and dragon fruit resulting from the best treatment formulation from the study. Then after the data obtained organoleptic test results were analyzed using a non-parametric test (Friedman Test) to see the average level power received in the form of score of 1 - 5 with the categories of very dislike, dislike, rather like, like, like very much. The organoleptic test was conducted by 30 panelists.

\section{RESULTS}

\section{A. Acceptance of wet noodles}

The Graph 1 shows that the type of formula most favored by panelists from all aspects of an assessment is P1 with the use of 80-gram flour, 20 grams of cork fish bone flour and 50 grams of dragon fruit.

The results showed that after the addition of cork fish bone flour and dragon fruit with different additions, different panelist acceptance results were obtained. The highest rating of overall $\mathrm{P} 1$ preference was the addition of 20 grams of cork fish bone meal and 50 grams of dragon fruit. It can be seen that the higher the addition of cork fish bone flour and dragon fruit, the acceptance of the overall preference for wet noodles shows a tendency to be increasingly disliked. This situation is influenced by the appearance of color, aroma, taste, and texture as a whole.

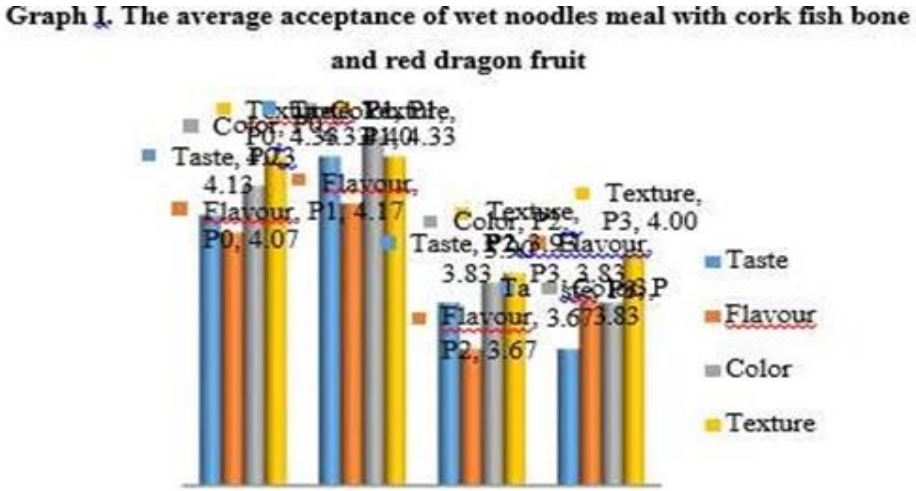

\section{B. Proximate Analysis}

Chemical analyses carried out include checking levels of protein, fat, ash content, water content. The results of the study of the nutritional content of the Wet Fish Flour Noodles Cork Fish and Dragon Fruit as in Table 2:

Table 2. Proximate Analysis of Wet Noodles from Cork Fish Bones And Red Dragon Fruit

\begin{tabular}{cc}
\hline Chemical & Levels \\
\hline protein & $5.46 \%$ \\
\hline Fat & $0.52 \%$ \\
\hline Carbohydrate & $26.51 \%$ \\
\hline Ash & $5.49 \%$ \\
\hline Water & $62.02 \%$ \\
\hline
\end{tabular}

The results of the analysis showed that the protein level of cork fish meal and dragon fruit bone flour products was less than $0.54 \%$ of the SNI noodle quality standard, which was at least $6 \%$. According to Nabil, 2005 states that the removal of protein is intended to increase the levels of minerals / ash contained in flour. 


\section{DISCUSSIONS}

There are significant differences in the addition of cork fish meal flour and dragon fruit towards the receptivity of the color of wet noodles. This is in line with research Afrinis, et al (2018) on the proportion of vermicelli with the addition of catfish bone meal, based on vermicelli taste, the majority of panelists can receive vermicelli flavors ranging from $60-80 \%$ [9]. The results showed that there were differences in the addition of catfish bone meal to vermicelli flavor. This shows that the more addition of catfish bone meal will change the taste of vermicelli. This is because the more addition of fishbone flour, the taste of vermicelli feels a little chalky because of the high calcium and phosphorus content in catfish bone meal. So that the higher the formulation of catfish bone flour causes the assessment of taste decrease. The color of wet noodles was influenced by the level of volume addition of the red dragon fruit peel extract solution. The greater the volume of the dragon fruit peel extract solution added to the noodles, the pink color of the wet noodles will be brighter [10].

There is a significant difference in flour addition cork fishbone and dragon fruit on the acceptability of the aroma of wet noodles. In line with research conducted by [11] on the Making of Calcium Wet Noodles by Addition of Tenggiri Fish Bone that in organoleptic tests the smell of Calcium wet noodles showed significantly different between treatments.

There is no significant difference in the addition of fishbone meal cork and dragon fruit on the texture of wet noodles. The use of fish bones in making wet noodles will affect the texture of the noodles [11].

The water levels of wet noodles with the addition of cork fish bone flour and dragon fruit is $62.02 \%$. The moisture content of the wet noodle formula is still within the range of the quality requirements of the wet noodles which is a maximum of $65 \%$. The thing that affects the absorption of water when steaming noodles is a protein denaturation. Denatured protein will reduce the ability of water absorption, water is used in the formation of protein networks protein will absorb and bind water to expand so that the protein in it is difficult to be released again, this Is especially the case for gluten (Khasanah and Hartati, 2016). So, with the addition of cork fish meal flour, the water content of wet noodles will increase.

The ash levels of the wet noodle formula is more than $5.44 \%$ of the SNI quality of the wet noodles which is a maximum of $0.05 \%$. The results of the analysis showed that the treatment of adding cork fish meal flour significantly affected the levels of the wet noodles produced. This is consistent with previous research which states that an increase in ash content to the addition of cork bone meal to crackers[7].

The results of the analysis of fat content in wet noodle products with the addition of bone meal cork fish and dragon fruit that is $0.52 \%$. The fat content in food is also affected during the heating and boiling process, not only fat as well as protein and carbohydratesb [13].

The results of the analysis of carbohydrate content in wet noodle products with the addition of cork fish meal flour and wet noodles were $26.51 \%$ [14]. The calcium content of wet noodles with the addition of cork fish bone flour and dragon fruit according to the calculation of survey nutria is $228.1 \mathrm{mg} / 100$ grams while the calcium content of ordinary wet noodles in the survey nutria analysis is only $7 \mathrm{mg} / 100$ grams it means that there is an effect of adding bone meal cork fish and dragon fruit against the calcium content of wet noodles.

\section{CONCLUSION}

The addition of cork fish bone flour and dragon fruit in the making of wet noodles with different proportions in each treatment can significantly affect the acceptability of wet noodles on taste, color, and aroma. However, there was no significant difference in effect on the acceptability of the texture of wet noodles.

\section{ACKNOWLEDGMENT}

We say thanks to Politeknik Kesehatan Palembang which has provided funding for students to conduct research.

\section{REFERENCES}

[1] G. Hou, Oriental noodles, vol. 43, no. C. 2001

[2] Yuliani, R. A. Sari, A. Emmawati, and K. P. Candra, "The Shelf Life of Wet Noodle Added by Gendarussa (Justicia gendarussa Burm. F.) Leaves Extract," Indones. J. Agric. Res., vol. 3, no. 1, pp. 23-30, 2020 .

[3] E. Lokaria and H. Harmoko, "The Benefits of Red Dragon Fruit ( Hylocereus polyrhizus ) Leather Juice and Organoleptic Testing to The Endurance of Wet Noodles 21. The Benefits of Red Dragon Fruit ( Hylocereus polyrhizus ) Leather Juice and Organoleptic Testing to The Endurance of We," no. December 2017, pp. 140-145, 2018.

[4] Yulianti, "Pengaruh Penambahan Tepung Ikan Cakalang Pada Mie Kering Yang Bersubtitusi Tepung Ubi Jalar Influence Of The Addition Of Flour Skipjack in Dry Noodles Substitution Of Sweet Potato Flour," pp. 8-15, 2018.

[5] R. Yenrina and A. Kasim, "Bioavailability of Protein and Calcium in Instant Noodle With Anchovy Fish Powder Mixed," 1993. 
[6] S. C. Bastos et al., "Fish filleting residues for enrichment of wheat bread: chemical and sensory characteristics," no. September, 2014.

[7] M. Putra, R. Nopianti, and H. Herpandi, "Fortifikasi Tepung Tulang Ikan Gabus (Channa Striata) Pada Kerupuk Sebagai Sumber Kalsium,” J. Teknol. Has. Perikan., vol. 4, no. 2, pp. 128-139-139, 2015.

[8] G. S. H. Yulianti Pratiwi, Abdul Rahim, "Karakteristik fisik dan kimia mie antioksidan dari pati sagu dengan ekstrak kulit buah naga merah," vol. 4, no. 5, pp. 553-558, 2016.

[9] A. Nur, V. Besti, H. D. Anggraini, F. I. Kesehatan, U. Pahlawan, and T. Tambusai, "Formulasi dan Karakteristik Bihun Tinggi Protein dan Kalsium dengan Penambahan Tepung Tulang Ikan Patin ( Pangasius hypopthalmus ) untuk Balita Stunting Formulation and Characterization of Rice Noodles High Protein and Calcium with Addition of Patin Fishbone Powder ( Pangasius hypopthalmus ) for Children Under Five Years Stunting," vol. 14, no. 2, pp. 157-164, 2018.

[10] Nurmilatina, "Sebagai Pewarna Alami Mie Utilization Super Red Dragon Fruit ( Hylocereus Costaricensis ) Bark As Natural Dyes For Noodles Super Red Dragon fruit ( Hylocereuscostaricensis ) bark not yet widely usewhen 30 $35 \%$ of all dragon fruit is the bark . Dragon frui," pp. 325333, 2015.

[11] F. S. Laili Susanti, Meizul Zukri, "Pembuatan Mie Basah Berkalsium dengan Penambahan Tulang Ikan Tenggiri (Somberomorus lineolatus)," vol. 1, pp. 35-44, 2011.

[12] I. H. Sufrotun Khasanah, "Pencampuran Pengadukan Pencetakan Pemotongan Pengukusan Analisa Gambar 1 Flowchart pembuatan mie basahdan ujinya," vol. 1, no. 1, pp. 39-44, 2016.

[13] S. Istiqlaal, "Proximate Levels of Bone Bluefin Tuna Fish As Gelatinization By Product," IOSR J. Environ. Sci. Toxicol. Food Technol., vol. 11, no. 04, pp. 12-17, 2017.

[14] S. Sirichokworrakit, "Physical, Textural and Sensory Properties of Noodles Supplemented with Tilapia Bone Flour (Tilapia nilotica)," Int. J. Biol. Vet. Agric. Food Eng., vol. 8, no. 7, pp. 689-691, 2014. 